\title{
Sediment Oxygen Demand of a Leachate Pond at an Offshore Municipal Solid Waste Disposal Site 2 Years after the Site Was Closed
}

\author{
Shogo Sakita, Jun Nishimoto, Kazuyuki Nishimura \\ Department of Environmental Sciences, Prefectural University of Hiroshima, Shobara City, Japan \\ Email: sakita@pu-hiroshima.ac.jp
}

How to cite this paper: Sakita, S., Nishimoto, J. and Nishimura, K. (2018) Sediment Oxygen Demand of a Leachate Pond at an Offshore Municipal Solid Waste Disposal Site 2 Years after the Site Was Closed. Journal of Geoscience and Environment Protection, 6, 181-193.

https://doi.org/10.4236/gep.2018.64011

Received: February 26, 2018

Accepted: April 7, 2018

Published: April 10, 2018

Copyright $\odot 2018$ by authors and Scientific Research Publishing Inc. This work is licensed under the Creative Commons Attribution International License (CC BY 4.0).

http://creativecommons.org/licenses/by/4.0/

cC) (i) Open Access

\begin{abstract}
Various water quality parameters of a leachate pond at an offshore municipal solid waste disposal site were monitored. The $\mathrm{pH}$, dissolved oxygen (DO), and water temperature at the bottom of the leachate pond were measured during Sep. (the 1st period) and Nov.-Dec. (the 2nd period) of 2011. The results suggested that the stratification of water temperature in the pond had gradually broken down due to convection occurring between the end of the 1st period and the 2 nd period. The $\mathrm{pH}$ was almost constant at $10-11$ during the 1 st period and was approximately 11.5 during the 2 nd period. The DO was almost zero during both periods. An anaerobic batch experiment with sampled sediment was undertaken to elucidate the mechanism of material leaching from the sediment. DO decreased under all experimental conditions. With respect to oxidation reduction potential (ORP) and total sulfide in addition to DO, the condition most closely mimicking that of the site became the most anaerobic. The average sediment oxygen demand, $\mathrm{SOD}_{\text {ave }}$, was calculated using a brief numerical model based on batch experiment data. The $\mathrm{SOD}_{\text {ave }}$ was $1114.7 \mathrm{mg} / \mathrm{m}^{2} / \mathrm{d}$, indicating that at least $434 \mathrm{~g} / \mathrm{d}$ of oxygen must be supplied to the leachate pond to maintain the DO.
\end{abstract}

\section{Keywords}

Offshore Disposal Site, Leachate Pond, Sediment, Sediment Oxygen Demand

\section{Introduction}

In Japan, approximately $80 \%$ of municipal solid waste (MSW) is incinerated, both to reduce its volume and for sanitary treatment [1]. Particularly in urban areas, finding new sites for final disposal of wastes has become increasingly dif- 
ficult. It is thus necessary to develop strategies to manage MSW disposal sites in a more environmentally safe manner and to promote the reduction, reuse, and recycling of wastes at both the technological and legal levels.

Leachate discharged from a MSW landfill must be treated appropriately in accordance with its quality and volume [2]. Urban residents living near disposal sites may experience some unpleasantness due to odors associated with the landfill as well as potential health hazards due to gases emitted from the landfill site [3]. In addition, the color of the leachate can be worrying to residents [2]. Complaints regarding leachate color and/or hydrogen sulfide odors can be lessened by careful management of leachate pond water quality. It is therefore necessary to consider measures that will prevent deterioration of pond water quality.

For the purpose of generating data that would aid in development of appropriate methods for controlling the water quality in leachate ponds, the authors investigated a leachate pond at an offshore disposal site 2 years after the site was closed. Pond water and sediment were sampled and analyzed in 2011 (9 Aug.), and the water mass balance in the leachate pond was also examined [4]. At offshore disposal sites, most of the waste is submerged under seawater, and the velocity of water percolating through the waste layer is very slow [5]. Thus, water quality in the leachate pond may deteriorate significantly due to high nutrient and heavy metal levels, especially after disposal is completed, necessitating long-term management of sea area disposal sites [6] [7] [8].

In order to obtain detailed water quality data for the offshore MSW site leachate pond, the authors measured the $\mathrm{pH}, \mathrm{DO}$, and water temperature at the bottom of the leachate pond over an approximately 1-month period in September and November-December of 2011. Anaerobic batch experiments using sediment sampled on 9 Aug. were then conducted in order to characterize the elution of various materials from the leachate pond sediment. Based on DO data, sediment oxygen demand was calculated for use in developing a strategy to improve the water quality of the leachate pond.

\section{Materials and Methods}

\subsection{Correlation between Various Parameters in the Water-Sediment of the Leachate Pond [4]}

An overview of the targeted offshore MSW disposal site in Hiroshima Prefecture, Japan, is shown in Table 1 . This disposal site is a semi-aerobic type with a final cover soil after closing and has a structure to prevent the percolation of precipitation water. Schematic of the pond structure, and photo taken in 2011 of the leachate pond is shown in Figure 1.

The leachate pond was anaerobic type without stirring. Leachate from the disposal site is collected in a leachate pond and sent to a wastewater treatment facility for treatment by coagulation-sedimentation, neutralization, and sand filtration. Particularly in summer, there is an offensive odor associated with the site, mainly due to hydrogen sulfide gas, and there are many chironomids in 


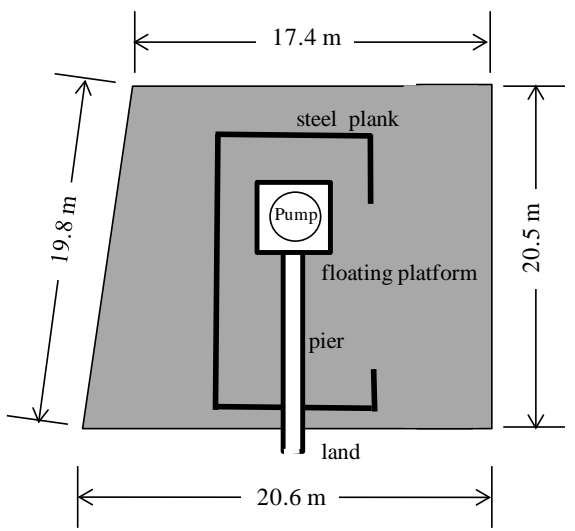

(a)

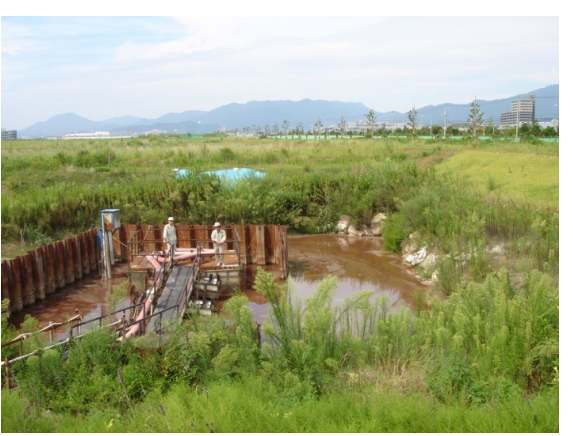

(b)

Figure 1. Condition of the leachate accumulation pond: (a) schematic of the pond structure, and (b) photo [4].

Table 1. Overview of the targeted offshore MSW disposal site [4].

\begin{tabular}{|c|c|c|}
\hline & Landfilled period & Jan. 1991-Mar. 2009 \\
\hline & Disposal area & $375,500 \mathrm{~m}^{2}$ \\
\hline & Volume & $4,855,000 \mathrm{~m}^{3}$ \\
\hline \multirow[t]{4}{*}{ Landfill } & Mean depth & $13.1 \mathrm{~m}$ \\
\hline & $\begin{array}{l}\text { Total weight of } \\
\text { disposed waste }\end{array}$ & $5,280,000$ tons \\
\hline & Waste types & $\begin{array}{c}\text { Inorganic wastes (sludge, gypsum board, incineration residues, } \\
\text { construction waste soil, debris, glass, and ceramic waste) }\end{array}$ \\
\hline & Area & $389.5 \mathrm{~m}^{2}$ \\
\hline \multirow[t]{2}{*}{$\begin{array}{l}\text { Leachate } \\
\text { pond }\end{array}$} & Mean depth & $2.9 \mathrm{~m}$ \\
\hline & Mean retention time & 37.8 days \\
\hline
\end{tabular}

flight in the area, resulting in complaints from neighboring residents.

Water and sediment in the leachate pond were sampled on 9 Aug., 2011. Samples were taken to the laboratory and kept frozen until analysis. They were thawed at every analysis and kept with the refrigerator until analysis. In this study, we analyzed pH (HM-50G, TOA DKK Corp.), EC (CM-30G, TOA DKK Corp.), SS, $\mathrm{COD}_{\mathrm{Mn}}\left(\mathrm{KMnO}_{4}\right.$ titration un der acidic condition), $\mathrm{NH}_{4}^{+}-\mathrm{N}$ (Hach 8155, Hach Corp.), $\mathrm{NO}_{2}^{-}-\mathrm{N}$ (Hach 10019), $\mathrm{NO}_{3}^{-}-\mathrm{N}$ (Hach 8039), total phosphorus (Hach 8190), $\mathrm{SO}_{4}^{2-}$ (Hach 8051), $\mathrm{Cl}^{-}\left(\mathrm{AgNO}_{3}\right.$ titration), $\mathrm{Ca}$, total $\mathrm{Cr}$ (Total $\mathrm{Cr}$ ), $\mathrm{Mn}, \mathrm{Fe}, \mathrm{Cu}, \mathrm{Zn}, \mathrm{Cd}$, and $\mathrm{Pb}$ using an ICP quantometer (SPS7800, Seiko Instruments, Inc.) after passing through a $1 \mu \mathrm{m}$ membrane filter in the pond water. Sediment samples were dried at $100^{\circ} \mathrm{C}$, and ignition loss (IL) was measured by heating at $800^{\circ} \mathrm{C}$ for $2 \mathrm{~h}$ in an electric furnace (FUL230FA, Advantec Inc.). Element contents of $\mathrm{Pb}, \mathrm{Cd}, \mathrm{Zn}, \mathrm{Cu}, \mathrm{Fe}$, total $\mathrm{Cr}, \mathrm{Mn}$ and $\mathrm{Ca}$ were analyzed by ICP after digestion in nitric and perchloric acid. Total sulfide in each sediment sample was analyzed by the gas detector tube (Hedoro-tec S, Gastec Corp.). 
These results have been reported [4]. It was thought that various chemical and microbial reactions would occur under conditions of high alkalinity and high salt concentrations in the water and sediment of the leachate pond [9] [10]. Thus, in this study, correlation coefficients for various parameters in both samples were calculated to examine this possibility qualitatively.

\subsection{Continuous Measurement of $\mathrm{pH}, \mathrm{DO}$, and Water Temperature in the Leachate Pond}

To examine the water quality of the leachate pond, continuous in situ measurements were made at the offshore landfill between 8-29 Sept., 2011 (1st period) and 20 Nov.-21 Dec., 2011 (2nd period). Data regarding pH, DO, and water temperature were collected using a $\mathrm{pH}$ and $\mathrm{DO}$ meter equipped with a data logger (DM-32P, TOA DKK Corp.). The meter was placed above the pond sediment. Measurements were taken every hour, and the data were collected after each measurement period.

\subsection{Batch Experiments with Sediment to Estimate Pond Water Characteristics}

For the purpose of estimating the pollution mechanism particularly in summer, sediment oxygen demand was determined in batch experiments with sediment sampled from the leachate pond. Sediment was sampled on 9 Aug, 2011 and then air dried at $50^{\circ} \mathrm{C}$. Leachate pond water sampled at the same time or pure water was used as a solvent. The properties of the sediment and leachate water are shown in Table 2. The Fe and Ca content in the sediment were high. The water was highly alkaline ( $\mathrm{pH}$ 9.5) and contained high concentrations of $\mathrm{Cl}^{-}$and

Table 2. Properties of the sediment and leachate water sampled on 9 Aug. [4].

\begin{tabular}{|c|c|c|c|c|}
\hline Sample & Parameter & Data & Parameter & Data \\
\hline \multirow{4}{*}{ Sediment } & $\mathrm{Ca}(\mathrm{mg} / \mathrm{kg})$ & 10,700 & $\mathrm{Cu}(\mathrm{mg} / \mathrm{kg})$ & 289 \\
\hline & $\mathrm{T}-\mathrm{Cr}(\mathrm{mg} / \mathrm{kg})$ & 132 & $\mathrm{Zn}(\mathrm{mg} / \mathrm{kg})$ & 723 \\
\hline & $\mathrm{Mn}(\mathrm{mg} / \mathrm{kg})$ & 741 & $\mathrm{~Pb}$ & 207 \\
\hline & $\mathrm{Fe}(\mathrm{mg} / \mathrm{kg})$ & 25,500 & Ignition loss (\%) & 7.2 \\
\hline \multirow{9}{*}{ Leachate water } & pH (-) & 9.5 & $\mathrm{Ca}(\mathrm{mg} / \mathrm{L})$ & 3.10 \\
\hline & $\mathrm{EC}(\mathrm{S} / \mathrm{m})$ & 1.604 & $\mathrm{~T}-\mathrm{Cr}(\mathrm{mg} / \mathrm{L})$ & 0.008 \\
\hline & $\mathrm{SS}(\mathrm{mg} / \mathrm{L})$ & 74 & $\mathrm{Mn}(\mathrm{mg} / \mathrm{L})$ & $<0.005$ \\
\hline & $\mathrm{COD}_{\mathrm{Mn}}(\mathrm{mg} / \mathrm{L})$ & 152.83 & $\mathrm{Fe}(\mathrm{mg} / \mathrm{L})$ & 0.026 \\
\hline & $\mathrm{NH}_{4}^{+}-\mathrm{N} \quad(\mathrm{mg} / \mathrm{L})$ & 0.41 & $\mathrm{Cu}(\mathrm{mg} / \mathrm{L})$ & 0.008 \\
\hline & $\mathrm{NO}_{2}^{-}-\mathrm{N} \quad(\mathrm{mg} / \mathrm{L})$ & 0.03 & $\mathrm{Zn}(\mathrm{mg} / \mathrm{L})$ & $<0.005$ \\
\hline & $\mathrm{NO}_{3}^{-}-\mathrm{N} \quad(\mathrm{mg} / \mathrm{L})$ & 5.4 & $\mathrm{Cd}(\mathrm{mg} / \mathrm{L})$ & $<0.005$ \\
\hline & $\mathrm{T}-\mathrm{P}(\mathrm{mg} / \mathrm{L})$ & 1.86 & $\mathrm{~Pb}(\mathrm{mg} / \mathrm{L})$ & 0.024 \\
\hline & $\mathrm{SO}_{4}^{2-} \quad(\mathrm{mg} / \mathrm{L})$ & 1100 & $\mathrm{Cl}^{-}(\mathrm{mg} / \mathrm{L})$ & 4,360 \\
\hline
\end{tabular}


$\mathrm{SO}_{4}^{2-}$. The particle size distribution of the sediment by sieving and a dynamic light scattering particle size analyzer (LB-550, Horiba Ltd.) is shown in Figure 2. The $50 \%$ cumulative passing diameter $\left(d_{50}\right)$ was $0.024 \mathrm{~mm}$, and visual inspection revealed a considerable amount of silt and slag. The number of sulfate-reducing bacteria in the sediment $\left(7.1 \times 10^{5}\right.$ cells/g-dry sediment $)$ was determined using the MPN protocol with modified ISA medium [11].

For batch experiments, sediment and solvent were placed in a polyethylene bottle (50 mm diameter, approximately $65 \mathrm{~mm}$ height) with an inner cap, and the bottle was then sealed and thoroughly mixed. The experimental conditions are shown in Table 3. For each experimental run, some preliminary trials were first performed to decide experimental conditions. A total of 11 undisturbed sediment cores were sampled on 9 Aug., 2011 using an acrylic pipe (44 mm inside diameter, approximately $1,000 \mathrm{~mm}$ height). From the relationship between the water depth in the leachate pond and the dry weight of sampled sediment [4], the liquid/solid ratio $[\mathrm{L} / \mathrm{S}]$ ranged from 5 to 10 . The bottles were placed in an incubator maintained at either $20^{\circ} \mathrm{C}$ or $30^{\circ} \mathrm{C}$. The conditions for run 4 , which most closely matched the conditions of the site, were leachate water used as the solvent, $\mathrm{L} / \mathrm{S} 5$, and incubation at $30^{\circ} \mathrm{C}$.

At the time the polyethylene bottle was removed from the incubator, the $\mathrm{pH}$, EC, ORP (D-72, Horiba, Ltd.), and DO were measured immediately. Water was filtered using a glass-fiber filter with a pore size of $0.45 \mu \mathrm{m}$ and then analyzed for

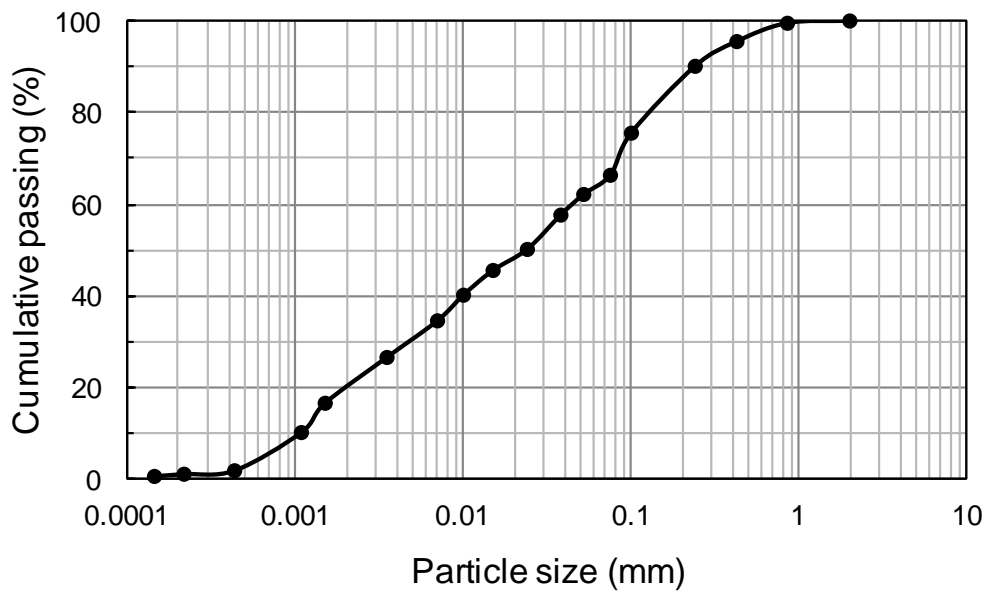

Figure 2. Sediment particle size distribution.

Table 3. Experimental conditions.

\begin{tabular}{ccccc}
\hline Run No. & Sediment (g-dry) & Solvent & L/S & Temperature $\left({ }^{\circ} \mathrm{C}\right)$ \\
\hline 1 & 10 & Pure water & 10 & 20 \\
2 & & Leachate water & & \\
3 & 20 & Pure water & 5 & 30 \\
4 & & Leachate water & & \\
\hline
\end{tabular}


$\mathrm{COD}_{\mathrm{Mn}}, \mathrm{NH}_{4}^{+}-\mathrm{N}, \mathrm{NO}_{2}^{-}-\mathrm{N}, \mathrm{NO}_{3}^{-}-\mathrm{N}, \mathrm{T}-\mathrm{P}, \mathrm{SO}_{4}^{2-}, \mathrm{Ca}, \mathrm{T}-\mathrm{Cr}, \mathrm{Mn}, \mathrm{Fe}, \mathrm{Cu}, \mathrm{Zn}$, $\mathrm{Cd}, \mathrm{Pb}$, and $\mathrm{Cl}^{-}$. Sediment was collected from the bottle and kept frozen until analysis. After thawing, the water content of the sediment was measured, and T-S was analyzed. The experiment was conducted in the shade. Results are reported as the mean of 3 samples collected at each sampling time.

\section{Results and Discussion}

\subsection{Correlation between Various Parameters in the Water-Sediment of the Leachate Pond}

Figure 3 shows the correlation between various parameters examined in the water and sediment samples collected on 9 Aug, and only correlations satisfying are shown in the figure. Positive correlations are shown by solid lines, and negative correlations are indicated by dashed lines. In the sediment, Fe was strongly correlated with pond water parameters $\left(\mathrm{pH}, \mathrm{EC}, \mathrm{NH}_{4}^{+}, \mathrm{T}-\mathrm{P}, \mathrm{Ca}, \mathrm{Fe}, \mathrm{Cl}^{-}\right) . \mathrm{Ca}$ was correlated with $\mathrm{pH}, \mathrm{COD}, \mathrm{NH}_{4}^{+}, \mathrm{Ca}$, and $\mathrm{Fe}$ in pond water parameters. In the pond water, $\mathrm{COD}, \mathrm{Ca}$, and $\mathrm{pH}$ were correlated more with sediment parameters. The $\mathrm{pH}$ of the pond water was not correlated with any other water parameter, but it was correlated with $\mathrm{IL}, \mathrm{Ca}, \mathrm{Fe}$, and $\mathrm{Zn}$ in the sediment. This indicates that the $\mathrm{pH}$ in the pond water is influenced by elution of $\mathrm{Ca}$ from the sediment and by the inflow of fresh leachate from the landfilled layer.

With respect to organic substances, the sediment IL, which was $7.2 \%-12.1 \%$ in each sample, was correlated only with pond water $\mathrm{pH}$. Pond water COD was correlated with $\mathrm{Ca}, \mathrm{T}-\mathrm{Cr}, \mathrm{Mn}, \mathrm{Cu}$, and $\mathrm{Zn}$ but was not correlated with any other water parameter. As chlorophyll-a was not detected in any of the samples, the pond water COD was thought to be derived from landfilled waste that was not incinerated. Especially in summer, it was anticipated that the DO would be almost completely consumed and that the sulfate-reducing activity would be high,

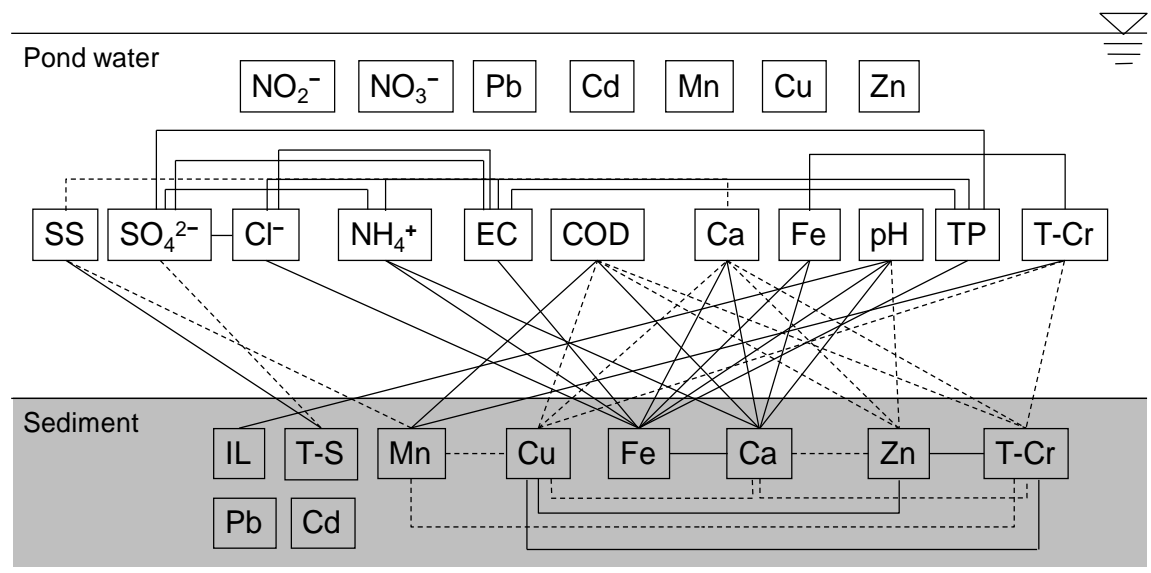

Figure 3. Correlation between various parameters in the water-sediment of the leachate pond. Only correlation coefficients between each parameter ( $r$ ) satisfying $|r| \geq 0.8$ are shown. Positive and negative correlations are shown by solid lines and dashed lines, respectively. 
as T-S and $\mathrm{SO}_{4}^{2-}$ were negatively correlated $(r=-0.87)$. Of the heavy metals identified in the pond water ( $\mathrm{Cr}(\mathrm{VI}), \mathrm{Mn}, \mathrm{Fe}, \mathrm{Cu}, \mathrm{Zn}, \mathrm{Cd}$, and $\mathrm{Pb}$ ), none of them exceeded the effluent standard in Japan.

\subsection{Continuous Measurement of $\mathrm{pH}, \mathrm{DO}$, and Water Temperature in the Leachate Pond}

Figure 4 shows the results of the continuous measurement of $\mathrm{pH}, \mathrm{DO}$, and water temperature above the sediment of the leachate pond. Lost data between 23 Nov and $13 \mathrm{Dec}$ in the 2 nd period are indicated by dashed lines. The daily average temperature in Hiroshima City is shown for the same periods [12]. Although the patterns of change in the pond water temperature and the temperature in Hiroshima City were similar during the 1st period, the water temperature was about $2^{\circ} \mathrm{C}-10^{\circ} \mathrm{C}$ higher than the temperature during the 2 nd period. These data suggest that the temperature stratification in the water in the leachate pond had gradually broken down as a result of convection beginning in November. The $\mathrm{pH}$ during the 1 st period was approximately $10-11$, and during the 2 nd period, the $\mathrm{pH}$ was nearly constant at about 11.5 . The $\mathrm{pH}$ was high because about $70 \%$ of the land filled waste was incineration residues.

The DO was almost zero during both the 1 st and 2 nd periods. During the 1 st period, the pond water temperature was about $20-27^{\circ} \mathrm{C}$, and there was an odor, due primarily to hydrogen sulfide. In addition, the Fe content of the sediment was high $(2.55 \%)$ and the color of the pond water seemed to be reddish-brown due to the presence of $\mathrm{Fe}(\mathrm{II})$. The absence of DO was attributed primarily to consumption by microorganisms. During the 2 nd period, the water temperature was about $13^{\circ} \mathrm{C}-21^{\circ} \mathrm{C}$, and there was no smell around the pond. The color of the pond water was blackish-brown. It was suggested that DO supplied to the bottom of the pond by convection was consumed by chemical oxidation of $\mathrm{Fe}(\mathrm{II})$ and sulfide generated in the summer rather than by microorganisms.

\subsection{Batch Experiment with Sediment}

DO, ORP, pH, and EC results are shown in Figure 5. The DO declined in all

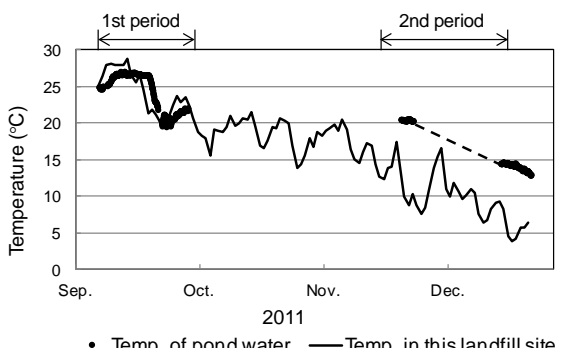

(a)

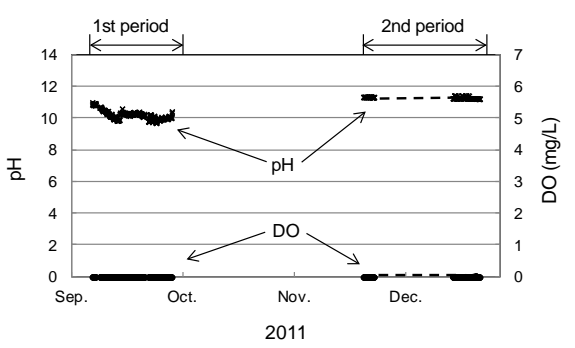

(b)

Figure 4. Results of continuous measurements in the leachate pond. (a) Water temperature in the leachate pond. The daily average of the temperature of Hiroshima City is shown for the same time period [12]; (b) $\mathrm{pH}$ and DO. Note that the broken line between 23 Nov. and $13 \mathrm{Dec}$. in the 2 nd period indicates data loss. 

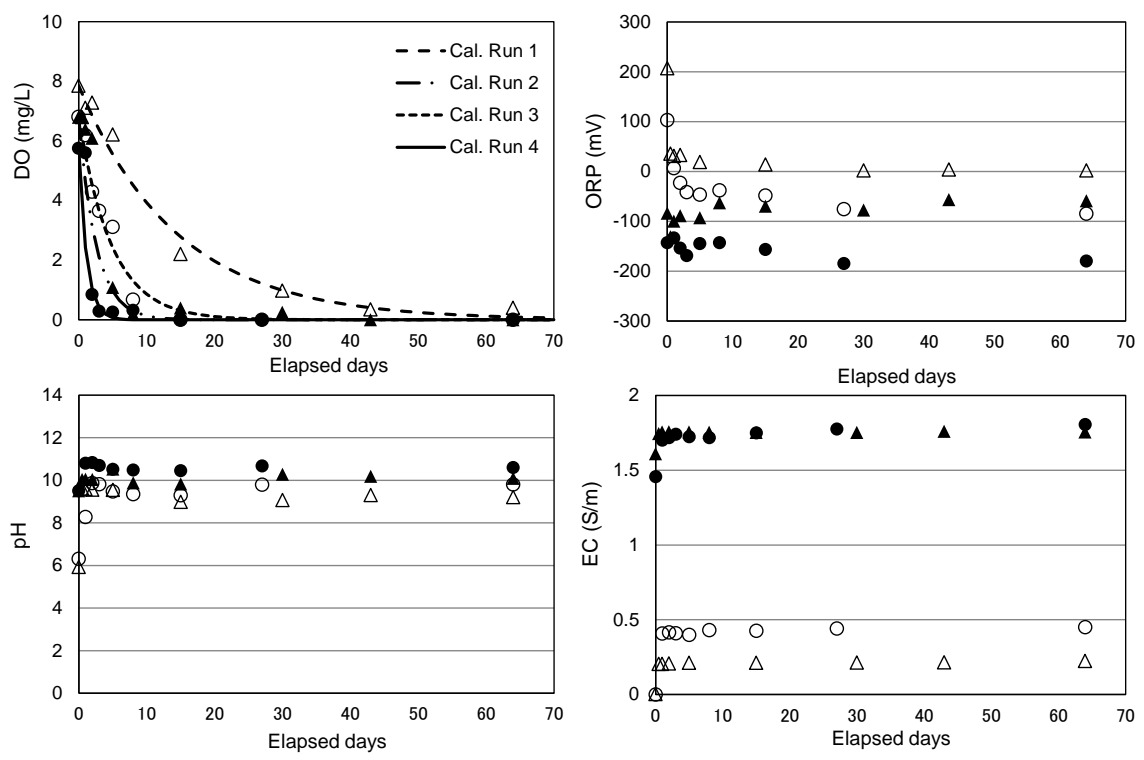

$\triangle$ Run 1 (pure water, $20^{\circ} \mathrm{C}$ )

ORun 3 (pure water, $30^{\circ} \mathrm{C}$ )

$\Delta$ Run 2 (leachate, $20^{\circ} \mathrm{C}$ )

- Run 4 (leachate, $30^{\circ} \mathrm{C}$ )

Figure 5. DO, ORP, pH, and EC results for the batch experiments. Lines in the DO graph show calculated data from curve fitting of the batch experiment DO concentration data using equation (2). The rate constant of oxygen consumption (L/kg/d), $k$, were $2.70,1.01$, 4.32 , and $1.23 \mathrm{~L} / \mathrm{kg} / \mathrm{d}$ for runs $1,2,3$, and 4, respectively.

experimental runs, and the rate of decline was highest with leachate used as the solvent and $30^{\circ} \mathrm{C}$ as the incubation temperature. Particularly in run 4 (leachate, $\mathrm{L} / \mathrm{S} 5,30^{\circ} \mathrm{C}$ ), which most closely matched the conditions of the site, the DO declined to almost zero within 3 days. The lowest rate of DO consumption $(0.40$ $\mathrm{mg} / \mathrm{L}$ after 64 days) was observed in run 1 (pure water, $\mathrm{L} / \mathrm{S} 10^{\circ} \mathrm{C}, 20^{\circ} \mathrm{C}$ ). The ORP also decreased with time, reaching $-180 \mathrm{mV}$ in run 4 and $-60 \mathrm{mV}$ in run 2 (leachate, $\mathrm{L} / \mathrm{S}=10^{\circ} \mathrm{C}, 20^{\circ} \mathrm{C}$ ). In runs 1 and 3 , which used pure water as the solvent, the $\mathrm{pH}$ rose immediately after the beginning of the experiment, reaching approximately pH 9 - 10 and then remaining stable. In contrast, in runs 2 and 4, which used leachate water as the solvent, the $\mathrm{pH}$ was approximately $10-10.5$ and did not fluctuate considerably throughout the experiment. The EC was almost constant in each run, although it did rise immediately after the beginning of the experiment, suggesting that elution of ions from the sediment reached equilibrium very soon after the experiment began. The trends in metal concentrations were similar to the trend for EC. None of the metal concentrations exceeded the effluent standard in Japan, and almost all were present at levels at least 10 times lower than the effluent standard during the experimental period.

Figure 6 shows the results of $\mathrm{COD}_{\mathrm{Mn}}, \mathrm{NH}_{4}^{+}-\mathrm{N}, \mathrm{NO}_{3}^{-}-\mathrm{N}$, and T-S analyses. $\mathrm{COD}_{\mathrm{Mn}}$ rose gradually and then became constant. As for the amount of increase in $\mathrm{COD}_{\mathrm{Mn}}$ over the experimental period, it was largest in run 3, at $131.1 \mathrm{mg} / \mathrm{L}$, followed by run 4 (in which the condition most closely mimicked those of the 

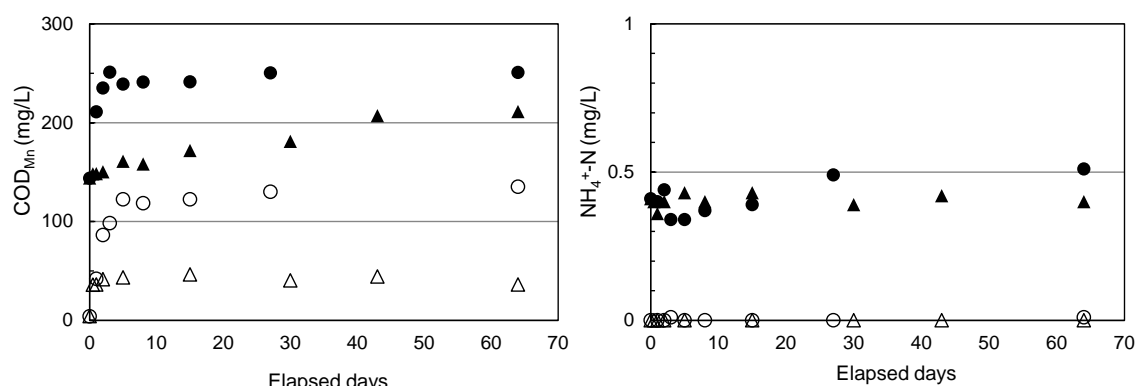

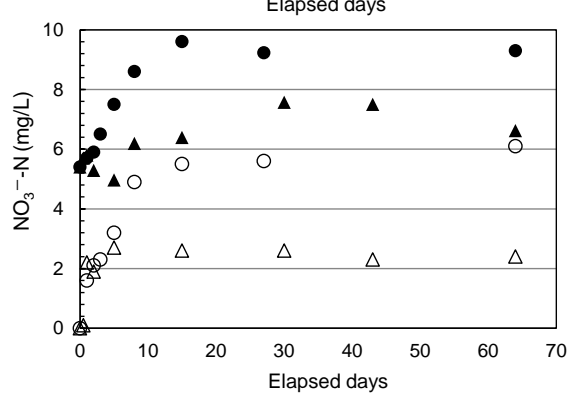

$\triangle$ Run 1 (pure water, $20^{\circ} \mathrm{C}$ )

ORun 3 (pure water, $30^{\circ} \mathrm{C}$ )

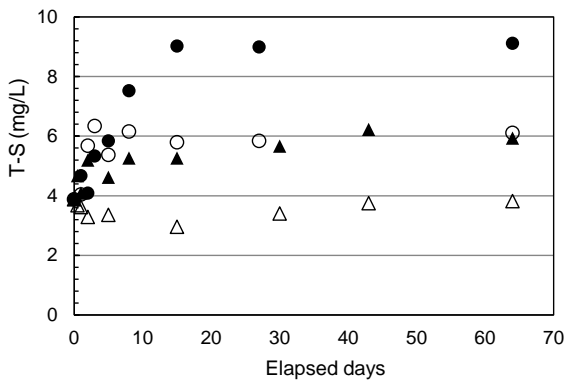

$\Delta$ Run 2 (leachate, $20^{\circ} \mathrm{C}$ )

- Run 4 (leachate, $30^{\circ} \mathrm{C}$ )

Figure 6. $\mathrm{COD}_{\mathrm{Mn}}, \mathrm{NH}_{4}^{+}-\mathrm{N}, \quad \mathrm{NO}_{3}^{-}-\mathrm{N}$, and $\mathrm{T}-\mathrm{S}$ results for the batch experiment.

site), at $107.1 \mathrm{mg} / \mathrm{L}$. The $\mathrm{NO}_{3}^{-}-\mathrm{N}$ concentration rose, similar to the $\mathrm{COD}_{\mathrm{Mn}}$, whereas there was little change relative to the initial state for $\mathrm{NH}_{4}^{+}-\mathrm{N}$. The rise in $\mathrm{NO}_{3}^{-}-\mathrm{N}$ concentration could only be explained by diffusion from the sediment. With respect to the amount of increase in $\mathrm{NO}_{3}^{-}-\mathrm{N}$ during the experimental period, it was greatest in run 3 (pure water, $\mathrm{L} / \mathrm{S} 5,30^{\circ} \mathrm{C}$ ), at $6.1 \mathrm{mg} / \mathrm{L}$, followed by run 4 (which most closely mimicked the site conditions), at 3.9 $\mathrm{mg} / \mathrm{L}$, a trend similar to $\mathrm{COD}_{\mathrm{Mn}}$.

The amount of increase in T-S was the greatest in run $4(5.23 \mathrm{mg} / \mathrm{L})$. This was thought to be due to the activity of sulfate-reducing bacteria following the decreases in DO and ORP. Run 3, which used pure water as the solvent, exhibited a $2.23 \mathrm{mg} / \mathrm{L}$ increase in T-S, which was attributed to the reduction of residual $\mathrm{SO}_{4}^{2-}$ in the sediment. In run 2, which used leachate water as the solvent and incubation at $20^{\circ} \mathrm{C}$, the T-S concentration rose $2.05 \mathrm{mg} / \mathrm{L}$.

The optimum temperature for many sulfate-reducing bacteria is thought to be $25^{\circ} \mathrm{C}-30^{\circ} \mathrm{C}$ [13]. Run 2 appeared to provide a micro-environment suitable for the growth of sulfate-reducing bacteria, even though some nitrate acid remained and the surrounding temperature was $20^{\circ} \mathrm{C}$. Other studies have reported that sulfate-reducing activity occurs at a $\mathrm{SO}_{4}^{2-}$ /COD stoichiometry of $\geq 0.67$ [14], [15]. In the present study, this stoichiometry was exceeded in all runs.

From the results of the batch experiment, sediment oxygen demand was calculated using a brief numerical model [16]. When the oxygen consumption rate is in proportion to the $\mathrm{DO}$ concentration, the following equation holds:

$$
V \frac{\mathrm{d} C}{\mathrm{~d} t}=-k C m
$$


where $C$ represents the DO concentration $(\mathrm{mg} / \mathrm{L}), t$ represents time from the start of the experiment (days), $V$ represents solvent volume $(0.1 \mathrm{~L}), \mathrm{m}$ represents the weight of sediment used in the experiment (kg-dry), and $k$ represents the rate constant of oxygen consumption ( $\mathrm{L} / \mathrm{kg} / \mathrm{d})$.

Solving Equation (1) under the initial condition $\left(C=C_{0}\right.$ at $\left.t=0\right)$, the following equation is obtained:

$$
C=C_{0} \mathrm{e}^{\frac{k m}{V} t}
$$

From curve fitting of the batch experiment DO concentration data using Equation (2) (see Figure 5), $k$ values of $2.70,1.01,4.32$, and $1.23 \mathrm{~L} / \mathrm{kg} / \mathrm{d}$ were obtained for runs $1,2,3$, and 4 , respectively.

The average oxygen demand rate per unit area (designated average sediment oxygen demand [ $\left.\mathrm{SOD}_{\text {ave }}\right]$ in this study) [17] was calculated using Equation (3):

$$
\mathrm{SOD}_{\text {ave }}=-\frac{1}{T} \cdot \frac{1}{S} \int_{0}^{T} \frac{\mathrm{d} C}{\mathrm{~d} t} \mathrm{~d} t
$$

where $\mathrm{SOD}_{\text {ave }}$ is expressed as $\mathrm{mg} / \mathrm{m}^{2} / \mathrm{d}, T$ represents the period during which the DO was almost zero (days), and $S$ represents the sectional area of the polyethylene bottle $\left(\mathrm{m}^{2}\right)$.

When calculating the $\mathrm{SOD}_{\text {ave }}$ using the results of run 4 (the conditions of which most closely matched the conditions of the site) and $T=3$ days, a value of $1114.7 \mathrm{mg} / \mathrm{m}^{2} / \mathrm{d}$ was obtained. The area of the leachate pond was $389.5 \mathrm{~m}^{2}$ (see Table 1), and the mean water volume of the pond was $1185 \mathrm{~m}^{3}$, with a range of 800 to $2000 \mathrm{~m}^{3}$ after the disposal site was closed [4]. It was concluded that an oxygen demand of approximately $434 \mathrm{~g} / \mathrm{d}$ would be required to maintain DO in the pond in the summer.

Factors influencing leachate pond water quality include the composition of the landfilled waste, the time elapsed after landfilling, the landfilling method, chemical and microbial reactions occurring in the pond, and weather conditions, such as temperature and precipitation [18]. To prevent deterioration of the pond water quality, it is necessary to consider measures such as dredging [19] in addition to supplying oxygen by aeration in relation with the total cost [20] [21] [22] [23]. These measures must lead to a decrease in the load on leachate treatment equipment.

\section{Conclusions}

In this study, the $\mathrm{pH}, \mathrm{DO}$, and water temperature at the bottom of a leachate pond at an offshore MSW disposal site were measured in order to better understand factors affecting pond water quality following site closure. An anaerobic batch experiment using sampled sediment was also conducted to characterize the elution of materials from the sediment. The sediment oxygen demand was calculated from the resulting data for use in developing methods to improve the quality of leachate pond water. The results of this study are as follows: 
The patterns of change in the leachate pond water temperature and the daily averaged temperature were similar during the 1st period (8-29 Sept., 2011), the water temperature was about $2^{\circ} \mathrm{C}-10^{\circ} \mathrm{C}$ higher than the temperature during the 2nd period (20 Nov.-21 Dec., 2011). It was thought that the water temperature stratification in the leachate pond had broken down as a result of convection developing in the winter. The $\mathrm{pH}$ was almost constant at $10-11$ during the 1 st period and approximately 11.5 during the 2 nd period. The DO was almost zero during both the 1 st and 2 nd periods.

In the anaerobic batch experiments with sampled sediment, the highest rate of decrease in DO was observed when leachate was used as the solvent and samples were incubated at $30^{\circ} \mathrm{C}$. With respect to ORP and T-S, the condition in which leachate was used as the solvent, the L/S was 5 , and samples were incubated at $30^{\circ} \mathrm{C}$ (conditions most closely mimicking those of the site) became the most anaerobic. T-S was also generated under the condition in which leachate was used as the solvent, the incubation temperature was $20^{\circ} \mathrm{C}$, and the $\mathrm{L} / \mathrm{S}$ was 10 . The data from these experiments suggested the existence of a micro-environment suitable for the growth of sulfate-reducing bacteria, even though the surrounding temperature was lower than the optimum temperature.

The $\mathrm{SOD}_{\text {ave }}$ was calculated from batch experiment $\mathrm{DO}$ data using a brief numerical model. The $\mathrm{SOD}_{\text {ave }}$ was $1114.7 \mathrm{mg} / \mathrm{m}^{2} / \mathrm{d}$, suggesting that in summer, it is necessary to supply approximately $434 \mathrm{~g}$ of oxygen per day to the leachate pond.

To satisfy Japanese effluent water standards, it is necessary to continue to manage for more than 20 years in general. It is necessary to shorten the management period, and control measures for the leachate pond are critical to the appropriate management of landfills.

\section{Acknowledgements}

The authors thank the Hiroshima Prefecture Environmental Protection Public Corporation for sampling at the offshore disposal site.

\section{References}

[1] Japan Ministry of the Environment (2012) Annual Report on Waste Management in Japan. Japan Ministry of the Environment, Tokyo. (In Japanese)

[2] Renou, S., Givaudan, J.G., Poulain, S., Dirassouyan, F. and Moulin, P. (2008) Landfill Leachate Treatment: Review and Opportunity. Journal of Hazardous Materials, 150, 468-493. https://doi.org/10.1016/j.jhazmat.2007.09.077

[3] Loizidou, M. and Kapetanios, E.G. (1992) Study on the Gaseous Emissions from a Landfill. Science of the Total Environment, 127, 201-210.

https://doi.org/10.1016/0048-9697(92)90503-K

[4] Sakita, S., Nishimoto, J. and Nishimura, K. (2014) A Survey on Characteristics of Leachate Pond in an Offshore Municipal Solid Waste Disposal Site. Journal of Material Cycles and Waste Management, 18, 348-355.

https://doi.org/10.1007/s10163-014-0343-x https://link.springer.com/article/10.1007/s10163-014-0343-x 
[5] Koga, D., Shimaoka, T., Sakita, S., Hanashima, M. and Kokubo, H. (2003) Settlement Characteristics of Incineration Residue and the Behavior of the Pollutant in a Sea Area Landfill Site. Symposium on the 9 th International Waste Management and Landfill (in CD-ROM), 10 October 2003, Sardinia, 255-257.

[6] Kanai, T., Muraki, H., Fujii, K. and Momose, H. (1992) Variation of Water Quality in the Discharged Pond of Sea Area Landfill. Journal of Japan Waste Management Association, 45, 485-489. (In Japanese)

[7] Ishii, A. and Fukuhara, I. (2004) Change of Leachate Quality in Minami-Honmaki Landfill. Proceedings of the 25th Annual Conference of Waste Management Association, 28 January 2004, Nagoya, 282-284. (In Japanese)

[8] Nishio, T. (2006) Relationship between Water Quality and Microbial Activity in the Pretreatment Pond of a Sea-Based Solid Waste Disposal Site. Journal of Urban Living and Health Association, 50, 291-298. (In Japanese)

[9] Sah, L., Rousseau, D.P.L. and Hooijmans, C.M. (2012) Numerical Modelling of Waste Stabilization Ponds: Where Do We Stand? Water, Air, \& Soil Pollution, 223, 3155-3171. https://link.springer.com/article/10.1007/s11270-012-1098-4

[10] Fernandes, H., Viancelli, A., Martins, C.L., Antonio, R.V. and Costa, R.H.R. (2013) Microbial and Chemical Profile of a Ponds System for the Treatment of Landfill Leachate. Waste Management, 33, 2123-2128. https://doi.org/10.1016/j.wasman.2012.10.024

[11] Japan Sewage Works Association (1997) Sewage Water Testing Method, 623-627. (In Japanese)

[12] Japan Meteorological Agency http://www.jma.go.jp/jma/indexe.html

[13] Postgate, J.R (1984) The Sulphate-Reducing Bacteria. 2nd Edition, Cambridge University Press, Cambridge.

[14] Widdel, F. (1988) Microbiology and Ecology of Sulphateand Sulpur Reducing Bacteria. In: Zehnder, A., ed., Biology of Anaerobic Organisms, Wiley, New York, 456-486.

[15] Sivula, L.J., Va“isa"nen, A.O. and Rintala, J.A. (2007) Treatment of Leachate from MSWI Bottom Ash Landfilling with Anaerobic Sulphate-Reducing Process. Water Research, 41, 835-841. https://doi.org/10.1016/j.watres.2006.11.036

[16] Japan Society of Civil Engineering (2004) Formulas, Models and Tables in Environmental Engineering. 355.

[17] Higashino, M. (2011) Oxygen Consumption by a Sediment Bed for Stagnant Water: Comparison to SOD with Fluid Flow. Water Research, 45, 4381-4389. https://doi.org/10.1016/j.watres.2011.04.051

[18] Kjeldsen, P., Barlaz, M.A., Rooker, A.P., Baun, A., Ledin, A. and Christensen, T.H. (2002) Present and Long-Term Composition of MSW Landfill Leachate: A Review. Critical Reviews in Environmental Science and Technology, 32, 297-336. https://doi.org/10.1080/10643380290813462

[19] Giani, M., Gabellini, M., Pellegrini, D., Costantin, S., Beccaloni, E. and Giordano, R. (1994) Concentration and Partitioning of $\mathrm{Hg}, \mathrm{Cr}$ and $\mathrm{Pb}$ in Sediments of Dredge and Disposal Sites of the Northern Adriatic Sea. Science of the Total Environment, 158, 97-112. https://doi.org/10.1016/0048-9697(94)90050-7

[20] Butler, E., Hung, Y.-T., Al Ahmad, M.S., Yeh, R.Y.-L., Liu, R.L.-H. and Fu, Y.-P. (2015) Oxidation Pond for Municipal Wastewater Treatment. Applied Water Science, 7, 31-51. https://link.springer.com/article/10.1007/s13201-015-0285-Z 
[21] Kamaruddin, M.A., Yusoff, M.S., Aziz, H.A. and Basri, N.K. (2013) Removal of COD, Ammoniacal Nitrogen and Colour from Stabilized Landfill Leachate by Anaerobic Organism. Applied Water Science, 3, 359-366. https://link.springer.com/article/10.1007/s13201-013-0086-1

[22] Kale, S.S., Kadam, A.K., Kumar, S. and Pawar, N.J. (2010) Evaluating Pollution Potential of Leachate from Landfill Site, from the Pune Metropolitan City and Its Impact on Shallow Basaltic Aquifers. Environmental Monitoring and Assessment, 162, 327-346. https://link.springer.com/article/10.1007/s10661-009-0799-7 https://doi.org/10.1007/s10661-009-0799-7

[23] Gao, J., Oloibiri, V., Chys, M., Audenaert, W., Decostere, B., He, Y., Van Langenhove, H., Demeestere, K. and Van Hulle, S.W.H. (2015) The Present Status of Landfill Leachate Treatment and Its Development Trend from a Technological Point of View. Reviews in Environmental Science and Biol Technology, 14, 93-122.

https://link.springer.com/article/10.1007/s11157-014-9349-z

https://doi.org/10.1007/s11157-014-9349-Z 